\title{
Claims for damages arising from conduct prohibited under the Competition Act, 1998
}

\author{
Phumudzo S Munyai \\ $L L M$ \\ Senior Lecturer, College of Law, University of South Africa
}

\section{OPSOMMING \\ Eise vir skade voortvloeiend uit optrede wat verbied word deur die Wet op Mededinging, 1998}

\begin{abstract}
Hierdie artikel evalueer die regsraamwerk en sake (siviele eise) vir skade voortvloeiend uit verbode gedrag in terme van die Wet op Mededinging ('die Wet'). Die hoof uitgangspunt is dat die vermoë van individue en instansies (wat skade gely het as gevolg van sodanige verbode gedrag) om skade te eis teen verweerders, effektief sal bydra daartoe om toekomstige oortredings te voorkom en nakoming van die Wet te bevorder. Daar word kennis geneem daarvan dat die reëls met betrekking op siviele eise vir skade wat ontstaan as gevolg van verbode gedrag een van die mees onderontwikkelde areas van ons mededingingsreg is. Verskeie faktore mag die vermoë van klaers ondermyn om tot aksie oor te gaan in siviele howe vir skade wat voortspruit uit verbode gedrag ingevolge die Wet. Sodanige faktore sluit in swak geformuleerde en onvoldoende bepalings in die Wet wat handel met klaers se reg om siviele gedinge in te stel vir skade voortspruited uit verbode gedrag; en vrae rondom die gepastheid van siviele howe as geskikte forums om algemene mededingingskwessies te hanteer en die forums se rol in die evaluering en toekenning van skade gely deur mededinging. In die bespreking en analise wat volg, handel ek breedweg met hierdie kwesssies en ten slotte maak ek gepaste voorstelle om die situasie te verbeter.
\end{abstract}

\section{Introduction}

The most underdeveloped area of our competition law is the rules relating to civil claims for damages arising from conduct prohibited under the Competition Act. ${ }^{1}$ At the time of the preparation of this paper, only five cases, four of which were class action certification cases and were dealt with, at first, as a single case, had been decided. ${ }^{2}$ In terms of

89 of 1998.

2 Trustees for the Time Being for the Children's Resource Centre Trust $v$ Pioneer Foods (Pty) Ltd, Mukaddam v Pioneer Foods (Pty) Ltd [2011] ZAWCHC 102; Trustees for the time being of Children's Resource Centre Trust $v$ Pioneer Food (Pty) Ltd 20132 SA 213 (SCA); 20133 BCLR 279 (SCA); 20131 All SA 648 (SCA); Mukaddam v Pioneer Food (Pty) Ltd 20132 SA 254 (SCA); Mukaddam v Pioneer Foods (Pty) Ltd 20135 SA 89 (CC); 201310 BCLR 1135 (CC); and Nationwide Airlines (Pty) Ltd (in Liquidation) $v$ South African Airways (Pty) Ltd [2016] ZAGPJHC 213. 
academic writing, there are only two credible textbooks ${ }^{3}$ and a handful of accredited journal articles ${ }^{4}$ that have attempted to cover the subject. When one adds the fact that civil claims for damages for anticompetitive conduct under the South African Competition Act is procedurally and substantively different from its foreign law counterparts, particularly American antitrust and European competition law, it becomes too apparent that there is not much to work with for anyone wishing to write in this area.

In most discussions and conversations I have had with lay members of the public and students on matters related to the Competition Act, I have often fielded questions around 'whether consumers and companies adversely affected by conduct in contravention of the Competition Act receive any part of the money the offending firm pays as part of a consent agreement with the Competition Commission and as an administrative penalty by an order of the Competition Tribunal'? ${ }^{5}$ No, is my regular answer which, invariably, evokes surprise, and even disappointment, among my inquisitors. As is the norm, money paid by the offending firm pursuant to a consent order and as an administrative penalty imposed by the Competition Tribunal does not go to affected firms or consumers, but to the National Revenue Fund administered by the Treasury. ${ }^{6}$

In the nature of things, conduct by a producer or manufacturer found by competition authorities to constitute a prohibited practice may attract multiple suits from an endless chain of complainants. The complainants may range from direct customers (usually corporate customers) to indirect customers or end-users (usually individual consumers). The Competition Act does not preclude any of these customers and consumers, if they have suffered loss or damage as a result of conduct by a defendant found by competition authorities to constitute a prohibited practice, from pursuing action in a civil court for damages. This, as I shall show later, is slightly different from saying 'the Competition Act establishes a right for persons who have suffered loss as a result of conduct found by competition authorities to constitute prohibited practice, to pursue action in a civil court for damages'. 7 It is not clear

$3 \quad$ Brassey et al Competition Law (2002) 327-328; and Sutherland and Kemp Competition Law of South Africa (LexisNexis Online: last updated November 2015) par 12.3.7.

4 Moodaliyar, Reardon, and Theuerkauf 'The Relationship Between Public and Private Enforcement in Competition Law: A Comparative Analysis of South African, the European Union, and Swiss Law' 2010 SALJ 141-162; Mongalo and Nyembezi 'The Court Refuses to Grant a Certification Order in the Breadcartel Class Action Cases: A Closer Examination of the Western Cape judgement' 2012 Obiter 367-379; and De Vos 'Opt-in Class Action for Damages Vindicated by Constitutional Court: Mukaddam v Pioneer Foods CCT 131/12' 2013 TSAR 754-770.

5 The Competition Tribunal derives these powers from s 49D(1) (read together with 58(1)(b)) and 59 of the Competition Act.

6 S 59(4) of the Act. See also s 213 and 216 of the Constitution, 1996

7 The relevant provision of the Act, section 65(6), only provides that: 
whether the Act creates a unique statutory claim, or simply entitles complainants to pursue a common-law delictual claim. Affected parties may opt to pursue their damages claim against the defendant either individually, or collectively, by means of class action, if the requirements of a class action have been met. ${ }^{8}$ However, in practice, complainants seeking to claim damages in the civil courts, either individually or in class actions for loss suffered as a result of anticompetitive conduct, will face significant challenges.

This paper evaluates the legislative framework and case law on civil claims for damages arising from conduct prohibited under the Competition Act. The paper proceeds from the general point of view that the ability of complainants to claim damages from defendants for anticompetitive conduct should be one of the main features of the enforcement of the Act. As Scallan, Mbikiwa and Blignaut argues, "the ability of individuals and firms that have suffered harm, as a consequence of anticompetitive conduct, to claim damages against the defendant will contribute effectively in preventing future contraventions and increase the degree of compliance with the Act'.

The paper observes that there are various factors that may undermine the ability of complainants to pursue successfully actions in civil courts for damages arising from conduct found by competition authorities to constitute prohibited practice under the Competition Act. These includes poorly drafted and inadequate provisions of the Act dealing with complainants' right to institute civil claims for damages arising from anticompetitive conduct; and questions around the suitability of civil courts as appropriate forums for dealing with competition matters generally and their role in the assessment and award of competition

A person who has suffered loss or damage as a result of a prohibited practice may not commence an action in a civil court for the assessment of the amount or awarding of damages if that person has been awarded damages in a consent order confirmed in terms of section 49D(1).(Emphasis added).

8 As the Supreme Court of Appeal found in Children's Resource Centre supra n 2 par 28, these includes: the existence of a class identifiable by objective criteria; a cause of action raising a triable issue; common issues of fact or law raised by the claims of the members of the class; the appropriateness of the relief being sought; and a suitable representative in whose name the class action would be brought. However, in Mukaddam supra n 2 pars 34-35 the Constitutional Court warned that:

These requirements must serve as factors to be taken into account in determining where the interests of justice lie in a particular case. They must not be treated as conditions precedent or jurisdictional facts which must be present before an application for certification may succeed. The absence of one or another requirement must not oblige a court to refuse certification where the interests of justice demand otherwise. (My emphasis).

See also Sutherland and Kemp supra n 3 par 12.3.7 ff 40-42.

9 Scallan, Mbikiwa, and Blignaut 'Compensating for Harm Arising from Anticompetitive Conduct' paper presented at the Seventh Annual Competition Law, Economics and Policy Conference held between 5 \& 6 September 2013 at Sandton Sun, Sandton, Johannesburg, South Africa, 3. See also Moodaliyar et al supra n 4150 . 
damages. In discussion and analysis that follows, I deal broadly with these issues and make appropriate recommendations in the end.

\section{Background}

In terms of the size of its staff component, the Competition Commission is a relatively small organisation. It also does not have the budget to some of the investigated corporate defendants, and often wrestles in litigation before the Competition Tribunal and the courts. Due to a limited staff component and budget, it is not inconceivable that, in some cases where they feel that the competition breach is too trivial, they may make a decision not to take enforcement action. Whenever they feel that infringement of the Act in a particular instance raises important issues of law and policy, they may, however, be more proactive and aggressive in their enforcement of the Act.

But where the Commission decides not take enforcement action in respect of particular conduct (for example by not referring the relevant conduct to the Competition Tribunal for adjudication) a complainant is not without remedy. A complainant my still initiate a 'private enforcement' in its own name by referring the complaint directly to the Competition Tribunal for adjudication in terms of section 51(1) of the Act. ${ }^{10}$ However, even if a complainant is successful in a "private enforcement' action before the Tribunal in terms of section 51(1), the success may be of little financial significance. This is because a complainant does not receive any part of the amount that may be levied against the defendant as an administrative penalty by the Tribunal in terms of section 59 of the Act. The public character of the remedy that follows the successful litigation of a 'private enforcement' action by complainants under section 51(1) reveals that, despite the identity of a complainant in these proceedings, there is nothing 'private' about this enforcement action. A successful complainant would, after obtaining leave of the Competition Tribunal or Competition Appeal Court in terms of the prescribed certificate, still have to initiate a fresh civil claim to recover damages suffered as a result of conduct by the defendant that has been found by competition authorities to constitute prohibited practice under the Competition Act. ${ }^{11}$

This is what distinguishes private enforcement in South African competition law from similar processes in other jurisdictions, notably European competition law and American antitrust law. In these jurisdictions, firms directly affected by competition law transgressions will prosecute the defendant in the civil courts and seek damages without the involvement of, or dependent upon, any prior finding on the merits by a competition authority. ${ }^{12}$ In South African competition law, private

10 S 51(1) of the Act.

11 S 65(6)(b) of the Act.

12 In American antitrust law s 4(a) of The Clayton Act, 1914, 15 USCA § 12 provides that any person injured in his business or property by reason of 
enforcement is therefore limited to the pursuit of damages in the civil courts, following a prior finding on the merits against the defendant by competition authorities. ${ }^{13}$ In this regard, it is fair to say that competition law enforcement in South Africa is almost exclusively driven by public enforcement, where there is no direct financial reimbursement to complainants for the damage they may have suffered as a result of the defendant's anticompetitive conduct, nor is there a reward for the active role they may have played in the successful litigation against the defendant before competition authorities.

In other jurisdictions, particularly American antitrust law, private enforcement, which encompasses the pursuit for damages for losses arising from anticompetitive conduct, is an indispensable method in the effective enforcement of competition rules. ${ }^{14}$ The encouragement of private enforcement in the United States has ensured that American public antitrust enforcement agencies can focus their attention and resources on cases that raise important questions of law and policy, while not allowing anticompetitive conduct to go unpunished. ${ }^{15}$

The effective enforcement of the Competition Act will require the development, and even prioritisation, of our private enforcement regime to ensure that private complainants can successfully claim and recover damages suffered as a result of anticompetitive conduct. ${ }^{16}$ This will also

anything forbidden in the antitrust laws may sue in court and recover threefold the damages sustained and the cost of suit, including a reasonable attorney's fee. In the United States, over ninety percent of antitrust proceedings are initiated directly in the courts by private individuals seeking damages. With regard to private enforcement in European competition law a party who suffered damage as a result of anticompetitive conduct may in terms of recitals 3 and 7 of the Council Regulation (EC) No $1 / 2003$ of 16 December 2002 on the Implementation of the Rules on Competition laid down in Articles 81 and 82 of the Treaty of Europe also directly approach a court for damages. See Berrisch, Jordan, and Roldan 'E.U. Competition and Private Actions for Damages, The Symposium on European Competition Law' 2004 Northwestern Journal of International Law $\&$ Business 588-591; Woods, Sinclair, and Ashton 'Private Enforcement of Community Competition Law: Modernisation and the Road Ahead' 2004 Competition Policy Newsletter 31-37; and Whish and Bailey Competition Law (2012) 295-296.

13 This is because civil courts in South Africa have no jurisdiction to pronounce on the merits of a competition dispute, including the question whether a violation of the Competition Act has occurred. See s 65(2) of the Competition Act.

14 Scallan et al supra $n 924$.

15 Indeed in the United States public enforcement action by antitrust agencies has been overtaken by private enforcement because in private enforcement a plaintiff, if successful, may recover threefold the damage suffered, the socalled 'treble damages'. See LePage's Inc $v$ Minnesota Mining and Manufacturing Company (3M) 324 F 3d 141 (3rd Cir 2003) 146; Berrisch et al supra n 12 591; and Carstensen 'Remedies for Monopolization from Standard Oil to Microsoft and Intel: the Changing Nature of Monopoly Law from Elimination of Market Power to Regulation of its Use' 2012 Southern California Law Review 817.

16 Scallan et al supra $\mathrm{n} 9$. 
enhance complainants' constitutional right of access to justice embedded in section 34 of the Constitution. ${ }^{17}$ Although the Competition Act does not prevent persons who have suffered loss as a result of anticompetitive conduct from pursuing action in a civil court for damages, the usefulness of the relevant provision, in particular section 65 , to such persons is doubtful. I turn next to consider the provisions of section 65 of the Competition Act, which is relevant to civil actions for damages arising from prohibited conduct, with a view to highlight its important flaws.

\section{Section 65 of the Competition Act}

Section 65 provides, in parts relevant for current discussion, that 'a person who has suffered loss or damage as a result of a prohibited practice may not commence an action in a civil court for the assessment of the amount or awarding of damages, if that person has been awarded damages in terms of a consent agreement with the Competition Commission that has been confirmed by the Competition Tribunal'. ${ }^{18}$ The provision goes on to state that:

[...] if entitled to commence action in a civil court for damages, a person must - when instituting proceedings - file with the Registrar or Clerk of the Court a notice from the Competition Tribunal or Competition Appeal Court certifying, among others, that conduct constituting the basis for the claim has been found to be a prohibited practice in terms of the Competition Act. ${ }^{19}$

The right of a person to bring a claim for damages arising out of a prohibited practice, the provision states further, 'comes into existence on the date of the decision of the Competition Tribunal or, where there is an appeal, on the date that the appeal process is concluded' 20

When one looks at section 65 critically, the conclusion is inescapable that the provision does not sufficiently embolden persons who have suffered loss as a result of anticompetitive conduct to pursue actions for damages against defendants. It is one thing to say 'a person who has suffered loss or damage as a result of a prohibited practice may not commence an action in a civil court for damages, unless a certain condition is met', which is what section 65 says. $^{21}$ It is quite another to say 'a person who has suffered loss or damage as a result of a prohibited practice may commence an action in a civil court for damages, provide the following conditions are met', which is what section 65 does not say. The latter is more positive and generous and can be seen to create or establish a statutory claim or right. However, the former is too negative

17 S 34 of the Constitution provides that:

Everyone has the right to have any dispute that can be resolved by the application of law decided in a fair public hearing before a court or, where appropriate, another independent and impartial tribunal or forum.

18 S 65(6)(a) of the Act.

19 S 65(6)(b)(i).

20 S 65(9).

21 S 65(6)(a) 
and restrictive and can be seen as only permitting a right or claim that may exist under any other law, rather than create or establish a new one. ${ }^{22}$

In Trustees for the time being for the Children's Resource Centre Trust and Others $v$ Pioneer Foods (Pty) Ltd and Others, Mukaddam and Others $v$ Pioneer Foods (Pty) Ltd and Others, ${ }^{23}$ a case that, in part, concerned an application for certification to commence a class action on behalf of consumers who suffered damage as a result of conduct prohibited under the Competition Act, applicants identified their cause of action as arising from 'the unlawful actions of the respondents in contravention of the Competition Act'. ${ }^{24}$ It was not clear whether in this regard applicants framed their cause of action as a claim for damages arising from breach of a statutory duty, to be dealt with in accordance with common-law principles or a statutory action for damages arising directly from section 65 of the Competition Act. ${ }^{25}$ However, with regard to the latter, Van Zyl $\mathrm{AJ}$ expressed the view that 'I do not regard the provisions of section 65 of the Act to have created such a cause of action'. 26

On appeal, in Trustees for the time being of Children's Resource Centre Trust and Others $v$ Pioneer Food (Pty) Ltd and Others, ${ }^{27}$ the Supreme Court of Appeal, per Wallis J, endorsed Van Zyl AJ's view when it also held that section 65 of the Competition Act does not establish an exclusive statutory claim. ${ }^{28}$ This is because, Wallis J found, section 65 merely contemplates 'the possibility' of a claim for damages at the instance of a person who suffered loss or damage in consequence of a prohibited practice'. ${ }^{29}$ The provision, he found further:

does not state that a person who suffered loss or damage in consequence of a prohibited practice will have an action, nor does it purport to determine the requirements for such an action. ${ }^{30}$

The implications of Van Zyl AJ and Wallis J's findings in the above cases are that action for damages in the civil courts in terms of section 65 of the Competition Act may have to be dealt with in accordance with the usual common-law requirements of a delict. 31

22 However, Mongalo and Nyembezi argue that even on a cursory reading of $\mathrm{s}$ 65 of the Competition Act it is clear that the provision 'gives rise to a civil remedy', Mongalo and Nyembezi supra n 4374.

23 Children's Resource Centre WCHC case supra n 2.

24 Idem par 87.

25 This is because, as other observers note, it is not yet clear what precise cause of action is available to a claimant in terms of s 65, See Scallan et al supra $\mathrm{n} 91$.

26 Children's Resource Centre WCHC case supra n 2 par 87.

27 Children's Resource Centre SCA case supra n 2.

28 Idem pars 66-68.

29 Idem par 69.

30 Idem par 69

31 In Judd $v$ Nelson Mandela Bay Municipality [2011] ZAECPEHC 4 the Court, par 8, succinctly summarised these requirements as follows:

It is commonly recognised that an actionable wrong or delict has five 
However, the interpretation given to section 65 of the Competition Act by Van Zyl AJ and Wallis $J$ is not perfect. When the relevant parts of section 65 are considered, an argument can be made that the provision envisages a unique claim for damages arising from practices prohibited under the Competition Act different from a common-law delictual action. The provision, in relevant parts, states that:

A person who has suffered loss or damage as a result of a prohibited practice may not commence an action in a civil court for the assessment of the amount or awarding of damages if that person has been awarded damages in a consent order confirmed in terms of section 49D(1). ${ }^{32}$ (emphasis added).

If the civil courts were to proceed from the starting point that section 65 is the authority for them to exercise civil jurisdiction over conduct prohibited in terms of the Competition Act, they must apply its provisions faithfully. Civil actions in the courts in terms of section 65 of the Competition Act are for the assessment of the amount or awarding of damages. That is what the provision says and nothing more. Proceeding with a section 65 claim in terms of the common-law delictual requirements is different from what is envisaged by section 65 . The provision only mandates the courts to assess the amount or award damages, ${ }^{33}$ because all the relevant considerations that precede this exercise must have already been ventilated by the competition authorities.

The application of common-law delictual requirements to civil claims for damages arising from conduct prohibited under the Competition Act may result in an unacceptable situation where the civil courts inadvertently re-open the merits of a competition dispute. Civil courts have no authority to determine the merits of a competition disputes and may for this reason, arguably, not be a suitable forum for the assessment of the amount or awarding of damages in relation to the infringement of the Competition Act. ${ }^{34}$ I turn to this issue in my next discussion.

elements or requirements, namely; (a) the commission or omission of an act (actus reus), (b) which is unlawful or wrongful (wrongfulness), (c) committed negligently or with a particular intent (culpa or fault), (d) which results in or causes the harm (causation) and (e) the suffering of injury, loss or damage (harm).

See also Neethling 'Liability for Damage Caused by Veld, Forest and Mountain Fires’ 2011 SALJ 223223.

32 S 65(6)(a) of the Act.

33 Children's Resource Centre SCA case supra n 2 par 72.

34 Brassey et al supra n 328. 


\section{Suitability of the Civil Courts in Competition Matters and their Role in Competition Damages}

It is important to note that section 65 of the Competition Act, which deals with competition damages, does not seek to establish a separate system of its own which serves a purpose different from that of other provisions of the Act. The Act and all its provisions are aimed at the promotion and maintenance of competition. ${ }^{35}$ Just like awards for damages that may form part of consent orders and administrative penalties - which the Tribunal may impose on firms found to have contravened the $\mathrm{Act}^{36}$ competition damages are an effective means of ensuring compliance with the Act. Indeed public and private enforcement of competition law in South Africa are intertwined, as the availability of private damages is dependent upon a prior finding by the Tribunal or Competition Appeal Court. $^{37}$

While the general administration of the Competition Act falls under the exclusive jurisdiction of competition authorities, ${ }^{38}$ it seems odd that the assessment of the amount and awarding of damages arising from the infringement of the Act is entrusted to the civil courts. ${ }^{39}$ As a matter of practical logic, it is hard to see why the assessment of the amount and awarding of damages arising from conduct in violation of the Competition Act should not also form part of the exclusive domain of competition authorities. As a general rule of competition law enforcement, a firm's conduct cannot or should not be found to be anticompetitive and illegal unless there is a valid legal presumption, or it has been factually proven that the conduct in question has caused competitive harm to competitors or consumers. ${ }^{40}$ When civil courts address questions of harm and causation - as part of the requirements of a delict - in civil claims for damages arising from anticompetitive conduct, they are more likely inadvertently to re-open the question of competitive harm and thereby encroach into the domain of competition authorities.

\footnotetext{
$35 \mathrm{~S} 2$ of the Act.

36 S 49D(3) (read together with 58(1)(b)) and 59 of the Act.

37 Scallan et al supra n 925.

38 S 62(1) of the Act.

39 S 62(5) and 65(6)of the Act.

40 Competition Commission v Patensie Sitrus Beherend Beperk case no 37/CR/ Jun01 2002 ZACT 18 par 95; Sappi Fine Papers (Pty) Limited $v$ Competition Commission case no 62/CR/Nov01 2002 ZACT 26 pars 40 and 52; Competition Commission v South African Airways (Pty) Limited case no 18/ CR/Mar01 2005 ZACT 50 pars 101-105; Mandla-Matla Publishing (Pty) Ltd $v$ Independent Newspapers (Pty) Ltd case no 48/CR/Jun04 2006 ZACT 84 pars 77-78; Competition Commission and Another v British American Tobacco South Africa (Pty) Ltd case no 05/CR/Feb05 2009 ZACT 46 par 296; and Competition Commission v Telkom SA Ltd case no 11/CR/Febr04 2011 ZACT 39 par 99. See also Lewis Enforcing Competition Rules in South Africa (2013) 143.
} 


\section{Suitability of the Civil Courts in Competition Matters}

The ability of civil courts to deal appropriately with competition matters is a matter for debate. There are practical and jurisdictional reasons justifying keeping the civil courts out of competition matters altogether. The majority of officials from our competition law enforcement agencies have a general sense of uneasiness around the involvement of the civil courts in competition matters. Many believes that judges, the majority of whom have no knowledge or experience in competition law, are illequipped to deal appropriately with competition matters. This argument, though somewhat patronising to the judges, has some merit.

The current Competition Act is a relatively recent piece of legislation, having being in force for only less than 20 years. The Act is in a sense also revolutionary in that its language, concepts, principles, and institutions as well as the economic philosophy underpinning it are very distinct from those of its predecessors. ${ }^{41}$ Concepts such as 'abuse of dominance', 'anticompetitive harm', 'concerted practice', 'dominance', 'essential facility', 'excessive price', 'exclusionary act', and 'market power' have very distinct technical economic and legal meanings about which even seasoned competition practitioners often disagree. In view of the fact that Judges are generally drawn from a pool of long serving lawyers - many of whom may have been in legal practice long before the Act came into force - it is a real possibility that some may not have the requisite training, knowledge, and experience in this new field of law. For example, in Trustees for the time being for the Children's Resource Centre Trust and Others $v$ Pioneer Foods (Pty) Ltd and Others, Mukaddam and Others $v$ Pioneer Foods (Pty) Ltd and Others, ${ }^{42}$ the Western Cape High Court continuously referred, erroneously, to the Competition Tribunal as the 'Commission Tribunal'. ${ }^{43}$ Although this error was not fatal to the judgment of the Court, it at least shows that civil courts may not be familiar with the Competition Act and its new institutions.

In Woodlands Dairy (Pty) Ltd and Another $v$ Competition Commission ${ }^{44}$ the Supreme Court of Appeal equated an administrative penalty in competition law to a fine that may be imposed as a sentence in criminal proceedings, ${ }^{45}$ when there are obvious differences between the two. ${ }^{46}$ In a subsequent matter, Southern Pipeline Contractors and Another $v$ Competition Commission, ${ }^{47}$ the Competition Appeal Court would complain that:

41 The Regulation of Monopolistic Conditions Act 24 of 1955; and The Maintenance and Promotion of Competition Act 96 of 1979.

42 Children's Resource Centre WCHC case supra n 2.

43 Idem pars $14 ; 21 ; 64 ; 78$; and 79.

4420106 SA 108 (SCA); 20113 All SA 192 (SCA).

45 Woodlands Dairy supra n 44 par 10.

46 Federal-Mogul Aftermarket Southern Africa (Pty) Ltd $v$ The Competition Commission 20051 CPLR 50 (CAC) 67. See also Munyai 'Making Administrative Penalties Work' 2008 Juta's Business Law 23 25-26.

47 Case no 105/CAC/Dec 10; 106/CAC/Dec10 2011 ZACAC 6 par 9. 
[T] his equation of administrative penalties, which may be imposed in terms of s 59 of the Act, to criminal fines did not take any cognisance of the judgment of this Court in Federal-Mogul Southern Africa $v$ Competition Commission, ${ }^{48}$ nor to comparative authority cited in that judgment. ${ }^{49}$

In Fuel Retailers Association of Southern Africa $v$ Director-General: Environmental Management, Department of Agriculture, Conservation and Environment, Mpumalanga Province, ${ }^{50}$ a case which concerned action by a group of fuel retailers to prevent a new entrant from entering the market in the same area they traded, (White River, Mpumalanga) on socio-economic grounds - which included the viability of existing filling stations in the area if a new entrant is allowed to enter the market, ${ }^{51}$ the majority of the Constitutional Court judges decided in favour of the incumbent fuel retailers, effectively blocking the new entrant from entering the market. ${ }^{52}$

However, in his dissenting judgment Sachs J argued that he did not believe that the arrival of a new 'competitor' in the market doing the same business in competition with existing filling stations posed any measurable socio-economic threat - above the level of speculation. ${ }^{53}$ Unlike the majority, Sachs indicated that he preferred to allow the new entrant to enter the market and, for this reason, he would accordingly dismiss the appeal by the incumbent fuel retailers. ${ }^{54}$ Although Fuel Retailers was not formally pleaded and argued as a competition matter, but due to the centrality of the competition issues in this case the Constitutional Court, recognising the nature of its jurisdiction and own limitations on competition matters, should have referred the matter to the Competition Tribunal in order for the competition aspects of the case to be dealt with appropriately by a competent authority. 55

The Competition Act explicitly confers exclusive jurisdiction on competition matters to the competition authorities. ${ }^{56}$ However, in American Natural Soda Ash Corporation $v$ Competition Commission ${ }^{57}$ the

\footnotetext{
48 Supra $\mathrm{n} 46$.

49 Southern Pipeline Contractors supra $\mathrm{n} 47$.

50200710 BCLR 1059 (CC); 20076 SA 4 (CC).

51 Idem pars 5 , 9, and 16.

52 Idem pars 105 and 108.

53 Idem pars 112 and 118.

54 Idem par 119.

55 Although judicial etiquette requires that courts should only deal with and decide cases on the basis of issues pleaded and arguments made, the Constitution grants them powers to exercise discretion mero motu (of their own accord) to make appropriate interventions if the rule of law or interest of justice requires in order to find the most suitable and effective solution to the issues before them, which in this case could have included referring the matter to the Competition Tribunal, see Director of Public Prosecutions, Transvaal $v$ Minister for Justice and Constitutional Development 20094 SA 222 (CC); 20092 SACR 130 (CC); 20097 BCLR 637 (CC) pars 33-34. S 65(2) of the Competition Act also enjoins the courts to refrain from dealing with competition matters but to refer them to the Competition Tribunal.

$56 \mathrm{~S} 62(1)$ of the Act.

5720035 SA 655 (SCA).
} 
Supreme Court of Appeal, not to be outdone, held that the Competition Act had to be interpreted in accordance with section 168(3) of the Constitution, ${ }^{58}$ which would allow the Supreme Court of Appeal (as the final court of appeal in all matters - other than constitutional matters) appellate jurisdiction on competition matters over decisions of the Competition Appeal Court. ${ }^{59}$ Following the decision in American Natural Soda Ash, a number of subsequent cases went on appeal from the Competition Appeal Court to the Supreme Court of Appeal. ${ }^{60}$ To reverse this undesirable trend, section 168(3) of the Constitution was amended in order to restore the exclusive jurisdiction of competition authorities on competition matters. ${ }^{61}$

\section{The Role of the Civil Courts in Competition Damages}

Despite the fact that the Competition Act entrusts civil courts with the responsibility to assess the amount and award damages arising from anticompetitive conduct, ${ }^{62}$ the argument that civil courts are not an appropriate forum for this exercise is, in my view, persuasive. Section 65 of the Act, which is the primary authority for civil courts to exercise jurisdiction on competition damages, echoes the legislature's own scepticism over the expertise of civil courts in competition matters.

For example, when petitioned by a person claiming competition damages with notice from the Competition Tribunal or Competition Appeal Court, certifying that conduct constituting the basis for the civil claim has been found to be a prohibited practice, the civil court is bound by that finding. ${ }^{63}$ This is consistent with the principle of section 65 that 'if, in any action in a civil court, a party raises an issue concerning conduct that is prohibited in terms of this Act, the court must not consider the issue on its merits' ${ }^{64}$ If the issue raised in the civil court is one in respect of which the Competition Tribunal or Competition Appeal Court has made a finding, the civil court must apply the determination of the Tribunal or the Competition Appeal Court. ${ }^{65}$ And if the issue has never been determined by the Competition Tribunal or Competition Appeal Court, the civil court must refer the matter back to the Competition Tribunal to be considered on its merits. ${ }^{66}$ Failure by a court

58 S 168(3) of the Constitution stated that: 'The Supreme Court of Appeal may decide appeals in any matter. It is the highest court of appeal except in constitutional matters ....

59 American Natural Soda Ash supra n 57 pars 11-22.

60 Woodlands Dairy supra $\mathrm{n} 44$; Senwes Ltd $v$ Competition Commission case 118/2010 2011 ZASCA 99; Competition Commission v Yara (South Africa) (Pty) Ltd 20136 SA 404 (SCA); and Competition Commission v Computicket (Pty) Ltd case no 853/20132014 ZASCA 185.

$61 \mathrm{~S} 4$ of the 17 th Constitution Amendment. See also Computicket supra n 60 par 10.

$62 \mathrm{~S} 62(5)$ and 65(6)of the Act.

$63 \mathrm{~S} 65(7)$.

64 S 65(2).

65 S 65(2)(a)

66 S 65(2)(b) 
to adhere to these principles creates a real risk of intrusion into the domain of competition authorities by the courts.

\section{The Risk of Intrusion into the Domain of Competition Authorities by Civil Courts when Assessing Competition Damages}

The assessment of the amount of competition damages arising from anticompetitive conduct in the civil courts is not a straight forward process. At this stage of the development of our competition damages jurisprudence, the rules are not as yet clear. As I contended earlier, on a literal reading of the provisions of section 65(6) of the Act the role of the civil court under the provision is supposed to be a two-step process: the assessment of the amount of damages suffered by the plaintiff as a result of the defendant's conduct and awarding the damages. A court is not required to do more.

However, in Trustees for the time being of Children's Resource Centre Trust and Others $v$ Pioneer Food (Pty) Ltd and Others ${ }^{67}$ the Supreme Court of Appeal expressed the view that civil courts, as the forum to which parties who suffer loss as a result of anticompetitive conduct must turn in order to recover those losses, will apply 'conventional principles'. ${ }^{6}$ Conventional principles or requirements of a delictual claim are: conduct; wrongfulness; fault; causation; and harm. ${ }^{69}$ But all of these requirements, bar fault - which is not a requirement for competition law liability, must already have been considered in the decision of the Competition Tribunal. It is unthinkable that the competition authorities would make their decision without having considered whether there was anticompetitive and therefore illegal conduct which has caused harm to either competitors or consumers. Accordingly, the application of conventional delictual principles would amount to the re-examination of the very issues that the competition authorities have pronounced themselves on and which the civil courts have no jurisdiction to deal with.

In the few decided cases concerning civil claims for damages arising from breach of the Competition Act, there are a number of instances where this has happened. For example, in the Children's Resource Centre $^{70}$ class action certification case in order to pursue a claim for damages arising from price fixing on behalf of consumers in the Western Cape, the Supreme Court of Appeal found that "with regard to the proposed class it is clearly too broadly stated and the proposition that it includes virtually all consumers of bread in the Western Cape cannot be correct'. 71

67 Children's Resource Centre SCA case supra n 2.

68 Idem par 70.

69 Supra $n 31$.

70 Children's Resource Centre SCA case supra n 2.

71 Idem par 77. 
But the 'market definition', a concept of competition law used to identify the product(s) and geographic location(s) affected by the alleged anticompetitive conduct, as defined by the competition authorities clearly identified and accepted the Western Cape as one of the areas, in fact the primary area, in which the unlawful conduct of defendants were mostly clearly felt. ${ }^{72}$ Not only is it an encroachment on the domain of competition authorities for a civil court to suggest a different market definition for damages purposes than the one already defined by a competition authority in the merits case, it is also unfair to require plaintiffs to claim damages in a narrower market than the one in which the effects of the prohibited practice were felt.

In the Mukaddam and Others $v$ Pioneer Food (Pty) Ltd and Others ${ }^{73}$ Class action certification case, a group of bread distributors who purchased bread from the major bread producers and sold it to informal traders sought leave of the court to sue for damages against the bread makers, following a finding by competition authorities that the conduct of the bread makers, particularly the fixing of discounts the distributors would receive from the bread makers, constituted prohibited practice under the Competition Act. ${ }^{74}$ The Supreme Court of Appeal made a series of regrettable findings.

In response to the argument made by the distributors that the conduct of the bread producers caused them to suffer a reduction in gross profit in violation of the Competition Act and their constitutional right to trade, ${ }^{75}$ the Court found:

that would be inconsistent with competition, which necessarily entails that enterprises might be unprofitable and fail. Far from supporting the appellants' constitutional claims, the Competition Act, which the appellants find themselves linking to their constitutional claim, altogether undermines it. ${ }^{76}$

The Competition Act, the Court found further, "does not purport to protect the profits that an enterprise will make'. 77 On appeal, in Mukaddam v Pioneer Foods (Pty) Ltd and Others ${ }^{78}$ the Constitutional Court agreed with the Supreme Court of Appeal that while the Constitution provides citizens with a right to enter a trade, profession or occupation, it does not guarantee a right to successful outcomes once having done so. ${ }^{79}$ From a competition law perspective, these decisions of the Supreme Court of Appeal and Constitutional Court are wrong.

72 Indeed the competition dispute had its origin in the Western Cape, see Children's Resource Centre WCHC case supra n 2 pars 2-20; Children's Resource Centre SCA case supra n 2 par 5; and Mukaddam Constitutional Court case supra $\mathrm{n} 2$ par 5.

73 Mukaddam SCA case supra n 2.

74 Idem pars 1-3.

75 Idem par 5.

76 Idem par 8

77 Idem par 9.

78 Mukaddam Constitutional Court case supra n 2.

79 Idem par 71. 
Granted, the Constitution does not guarantee the right of enterprises to make profit. But, as Froneman J observed in his separate judgment in Mukaddam $v$ Pioneer Foods (Pty) Ltd and Others, ${ }^{80}$ it does not forbid the making of profit either. ${ }^{81}$ But Nugent JA couldn't be more wrong in Mukaddam and Others $v$ Pioneer Food (Pty) Ltd and Others ${ }^{82}$ when he said the Competition Act does not protect or guarantee the profits that an enterprise will make. ${ }^{83}$ It actually does. Section 8(c) of the Competition Act prohibits dominant firms from engaging in what it calls an 'exclusionary act'. An 'exclusionary act' is defined in section 1 of the Act as 'an act which impedes or prevents a firm from entering into or expanding within the market'.

The ability of a firm to enter into or expand within the market is inextricably intertwined with the firm's ability attract customers and make profit. If a firm's ability to attract customers and make profit is hampered by anticompetitive and unlawful conduct by a dominant firm, which all the bread producers were, ${ }^{84}$ that would constitute an exclusionary act in contravention of the Competition Act. As Froneman J correctly pointed out in his separate judgment in the Constitutional Court Mukaddam ${ }^{85}$ decision,

it would be wrong to find that there is no tenable claim in our law when someone alleges that, had there been no price fixing, his or her business could have been better off in the competitive environment that would have followed. ${ }^{86}$

Indeed there are plenty of cases in which the competition authorities have declared conduct by dominant firms which prevents other firms from attracting customers and make profits as exclusionary, anticompetitive, and unlawful. ${ }^{87}$

However, when regard is had to the recent South Gauteng local division competition damages claims decision in Nationwide Airlines (Pty) Ltd (in Liquidation) $v$ South African Airways (Pty) $L t d^{88}$ there seems to be light at the end of the tunnel. The claim arose from the finding of the Tribunal in 2010 that SAA had used anticompetitive means to divert customers away from Nationwide and other rivals. In the High Court Nationwide was able to recover damages arising from SAA's breach of

80 Supra $\mathrm{n} 78$.

81 Idem par 76

82 Mukaddam SCA case supra $\mathrm{n} 2$.

83 Idem par 9.

84 Children's Resource Centre WCHC case supra n 2 par 8; Mukaddam SCA case supra n 2 par 2; and Mukaddam Constitutional Court case supra n 2 par 3.

85 Mukaddam Constitutional Court case supra $\mathrm{n} 2$.

86 Idem par 76.

87 Nationwide Poles $v$ Sasol (Oil) Pty Ltd case no 72/CR/Dec03 2005 ZACT 17; South African Airways supra no 40; Competition Commission $v$ Senwes Limited case no 110/CR/Dec06 2009 ZACT 8; Nationwide Airlines (Pty) Ltd v South African Airways (Pty) Limited case no 80/CR/Sept06 2010 ZACT 13; and Competition Commission $v$ Telkom case supra $\mathrm{n} 40$.

88 Nationwide (in Liquidation) $v$ South African Airways supra $\mathrm{n} 2$. 
the Competition Act. ${ }^{89}$ There are a number of aspects of this decision that constitutes a positive contribution to our competition damages jurisprudence under section 65(6) of the Competition Act. For example, instead of dealing with the claim on the basis of conventional principles of delict, the Court approached the matter from the angle or perspective proposed in this paper: limiting itself to the assessment of the amount and award of damages without re-opening the issues decided by the competition authorities.

The Court accepted that the causation inquiry in a delictual claim for damages arising from breach of the Competition Act must not go to the merits of the case, but rather to the quantum of the damages. ${ }^{90}$ The Court accepted the findings of the Competition Tribunal and Competition Appeal Court on causation because it felt bound by those findings. ${ }^{91}$ It, accordingly, rejected SAA's argument, that there are other causal factors which contributed to Nationwide's downfall, as irrelevant because the Tribunal and Competition Appeal Court had already made a finding in that regard against SAA. ${ }^{92}$ The Court also made an award of damages that reflected or was based on the market definition as defined by competition authorities. ${ }^{93}$ However, it is not easy to tell at this early stage of the development of our competition damages claim jurisprudence what the full implications of the South Gauteng High Court decision in Nationwide will be - for a number of reasons.

Firstly, the approach of the Court in Nationwide appears to differ with the suggestion made by the Supreme Court of Appeal in Children's Resource Centre ${ }^{94}$ that when assessing competition damages under section 65(6) of the Competition Act a court must apply 'Conventional principles'. ${ }^{95}$ Secondly, the Nationwide decision does not even refer to or mention the two Supreme Court of Appeal decisions ${ }^{96}$ and the Constitutional Court judgment, ${ }^{97}$ by which it is bound - all of which deal with section 65(6) of the Competition Act. In fact, the South Gauteng High Court, as per Nicholls J, believed that the matter it was seized with was 'the first of its kind'. 98 Thirdly, in Nationwide the only issue for determination by the High Court was quantification of damages to be awarded to Nationwide because SAA had, for all intent and purposes, admitted delictual liability. ${ }^{99}$ Accordingly, it is not clear how useful this decision will be in cases where, as is customary in civil actions, delictual liability is disputed and must be established.

89 Idem pars 162-163.

90 Idem par 12.

91 Idem pars 48 and 120.

92 Idem par 49.

93 Idem par 158.

94 Children's Resource Centre SCA case supra n 2.

95 Idem par 70.

96 Mukaddam SCA case supra n 2; and Children's Resource Centre SCA case supra $\mathrm{n} 2$.

97 Mukaddam Constitutional Court case supra $\mathrm{n} 2$.

98 Nationwide (in Liquidation) v South African Airways supra n 2 par 1.

99 Idem pars 12 and 14. 
In such cases, where delictual liability is disputed and must be established, there is a reasonable possibility, in my view, that courts may inadvertently re-evaluate issues already decided by competition authorities in the merits case. This will be more so if they follow the guidance of the Supreme Court of Appeal, a court of higher authority than the South Gauteng local division, to apply 'conventional principles' when assessing and awarding competition damages in terms of section 65 of the Competition Act. ${ }^{100}$ This leaves us with one question that must be answered: to avoid these problems, would it not have been better for the Competition Act to grant competition authorities the powers to assess and award competition damages to complainants who suffer harm as a result of prohibited practices? As I conclude the paper, I will attempt to answer this question.

\section{Conclusion and Recommendations}

The dominant view held by most commentators is that the Competition Act precludes competition authorities from awarding damages to persons who suffered loss as a result of practices prohibited under the Act. ${ }^{101}$ This view is not entirely correct. In terms of section $49 \mathrm{D}(3)$ of the Competition Act a consent agreement between the Competition Commission and a respondent that may be confirmed as order of the Competition Tribunal may, with the consent of the complaint, include an award of damages to the complainant. ${ }^{102}$ There is no logic, in my view, to allowing damages for losses arising from anticompetitive conduct to be awarded to a complainant in terms of a consent order, without not also allowing the Tribunal and the Competition Appeal Court the same authority to award damages to a complainant as part of their general remedial powers.

The amendment of the Competition Act to provide for the authority of the Competition Tribunal and Competition Appeal Court to award damages to complaints would be a welcome and positive development. The current system, where only a civil court has authority to award competition damages to a complainant outside consent agreements/ orders, must be repealed as it has a number of pitfalls. Firstly, civil courts are not well suited for the role of assessing and awarding competition damages. Although civil courts have considerable experience in dealing with civil claims generally, competition damages under section 65(6) of the Act - which serves a purpose no different from damages that may be awarded by competition authorities pursuant to a consent order - raises significant challenges for the courts due to their proximity to the merits of a competition dispute. As Wilson observes, 'for the same reason that the determination of prohibited practices lies within the exclusive jurisdiction of competition authorities, the assessment and award of

100 Children's Resource Centre SCA case supra n 2 par 70.

101 Brassey et al supra $n 3$ 327; and Sutherland and Kemp supra n 3 par 12.3.7.

102 S 49D(3) (read together with section 58(1)(b)) of the Act. 
competition damages should fall within the exclusive jurisdiction of such bodies'. 103

Secondly, the long period it takes for complaints to recover damages for anticompetitive conduct in the civil courts undermines complainants' right of access to justice. A complainant must first wait for a decision of the Competition Tribunal (and the Competition Appeal Court in the event of an appeal) whether a particular practice is prohibited under the Act before commencing action in the high court for damages. Both the competition and civil proceedings usually take many years to complete. Depending on the nature and severity of the competition injury suffered by the complainant as a result of the prohibited practice, it is possible that, by the time the damages are awarded by a civil court, the complainant may already be out of business. Indeed that is what happened in Nationwide Airlines (Pty) Ltd (in Liquidation) $v$ South African Airways (Pty) Ltd. ${ }^{104}$

In such circumstances competition damages, when awarded, do not play an important role of promoting competitive conduct in the market, in addition to compensating complainants for their loss. Therefore, amending the Competition Act to enable competition authorities to award competition damages, as proposed here, will not only resolve theoretical jurisdictional questions. It will also contribute effectively towards enhancing complainants' constitutional right of access to justice, which may be undermined by the long period it takes to recover damages.

Finally, the structure and hierarchy of competition authorities also make them well equipped to deal effectively with damages arising from anticompetitive conduct. The competition authorities comprise the Competition Commission; the Competition Tribunal; and the Competition Appeal Court. Decisions of the Competition Commission are appealable to the Competition Tribunal, while the Tribunal's decisions are also appealable to the Competition Appeal Court. The Competition Appeal Court is a court of similar status to a high court, ${ }^{105}$ but with superior knowledge and experience on matters concerning the enforcement of the Competition Act. This is the court, together with its subsidiary institutions, with whom the responsibility to assess and award competition damages must lie.

103 Brassey et al supra n 3328.

104 Nationwide (in Liquidation) $v$ South African Airways supra $\mathrm{n} 2$.

105 S 36(1)(a) of the Competition Act. 